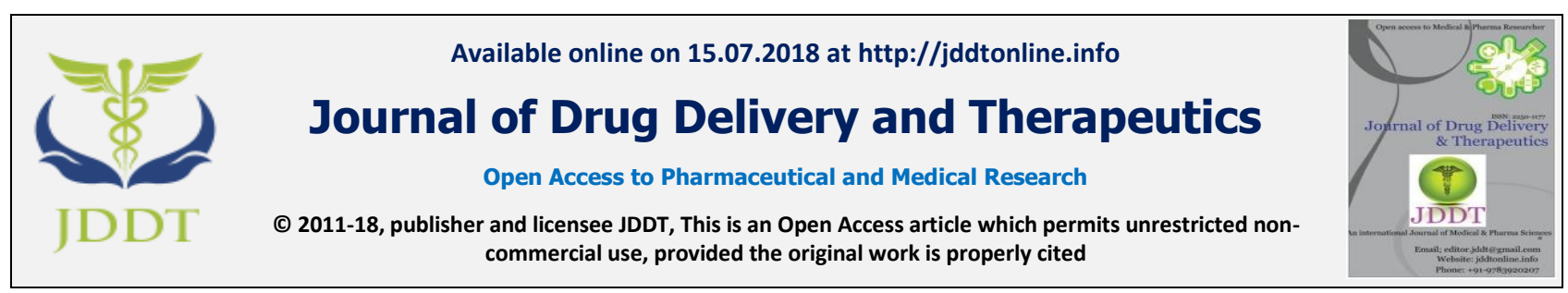

Open $\odot$ Access

Research Article

\title{
STUDY ON BIOSYSTEMATIC AND BIOACTIVITY OF Nocardiopsis flavescencs RRMVCBNR OBTAINED FROM NICHE HABITATS OF VALPARAI HILL STATION
}

\author{
Vineeth M. ${ }^{1 *}$ and R. Ragunathan ${ }^{2}$ \\ 641402,Tamilnadu, India. \\ ${ }^{2}$ Director, Centre for Bioscience and Nanoscience Research, Coimbatore -641021, Tamilnadu, India
}

${ }^{\mathbf{1}}$ Assistant Professor, Department of Biotechnology, Rathnavel Subramaniam College of Arts and Science, Coimbatore -

\begin{abstract}
In this work, the soil samples were collected niche habitats of Valparai hill station to screen the diversity of actinomycetes. The actinobacterial were isolated by serial dilution and plating method on starch peptone agar media. In totally 8 different morphological were isolated on the basis of colony characteristics on starch peptone agar and dominative isolate were screened and plated on point inoculation. RRMVCBNR 1 isolate was biosystamatically characterized on the basis of microscopic, colony morphology, biochemical and phenotypic studies. Phenotypic studies indicated that strains belonged to genus of Nocardiopsis which was further confirmed by genotypic studies based on 16S rRNA gene sequences followed by phylogenetic tree construction. 16S rRNA gene sequences of strain used in this study exhibited sequence similarity in the range of 99-100\% with those of selected isolate and it was identified as of Nocardiopsis flavescencs RRMVCBNR. The sequences of Nocardiopsis flavescencs 16S rRNA genes were deposited in genbank http://www.ncbi.nlm.nih.gov/genbank and received the accession number MG287120.The biological activity of Nocardiopsis flavescencs strain showed detectable antibacterial activity against Staphylococcus aureus and Klebsiella pneumonia has been studied.
\end{abstract}

Keywords: Nocardiopsis flavescencs, Starch peptone agar, Muller Hinton Agar, Mountain soil.SEM

Article Info: Received 21 May, 2018; Review Completed 07 July 2018; Accepted 07 July 2018; Available online 15 July 2018

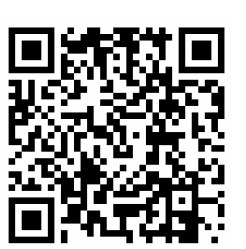

Cite this article as:

Vineeth M, Ragunathan R, Study on biosystematic and bioactivity of Nocardiopsis flavescencs RRMVCBNR obtained from niche habitats of Valparai hill station, Journal of Drug Delivery and Therapeutics. 2018; 8(4):282-290 DOI: http://dx.doi.org/10.22270/jddt.v8i4.1792

Vineeth M, Assistant Professor, Department of Biotechnology, Rathnavel Subramaniam College of Arts and Science, Coimbatore 641402, Tamilnadu, India.

\section{INTRODUCTION}

Actinobacteria are filamentous bacteria belonging to the phyla actinobacteria and the order actinomycetales ${ }^{1}$. Unlike bacteria, actinomycetes are unique in their morphology with extensive branching substrate and aerial mycelium bearing chain of arthrospores. The substrate mycelium and spores can be pigmented, which makes them most colourful and attractive among microbes. They possess cell wall characteristic of bacteria and filamentous nature of fungi. They are distributed ubiquitously in soil. The majority of the actinobacteria are free living saprophyte ${ }^{2}$.

Nocardiopsis spp. are distributed ubiquitously in the environment. The genus Nocardiopsis, a widespread group in phylum actinobacteria, has received much attention owing to its ecological versatility, and ability to produce a rich array of $80 \%$ bioactive metabolites ${ }^{3}$. Biosystamatic approaches for classification make use of morphological, physiological, and biochemical characters. The classical method described in the identification key is used in the identification of 
actinomycetes ${ }^{4}$. Phylogenetic diversity of actinomycetes cultured from soil and sequencing and analysis of $16 \mathrm{~S}$ rDNA from chosen representative isolates displayed the presence of members affiliated to actinobacterial genera: Streptomyces, Micromonospora, Nocardia, Nocardiopsis, Saccharopolyspora and Nonomuraea. The genus Nocardia was found to be the dominant among the isolates. Furthermore, rare actinomycete genus Nonomuraea was isolated for the first time from saline soil of Vidarbha region and agar plates they form lichenoid, leathery or powdery colonies ${ }^{5}$.

Its high environmental adaptability might be attributable to its genome dynamics, which can be estimated through comparative genomic analysis targeting microorganisms with close phylogenetic relationships but different phenotypes ${ }^{6}$.The major niche habitats range in the Valparai hills of the Western Ghats that is rich biodiversity, microflora and indigenous population. It is located in the Western boundary range in Coimbatore district in the Southwest of Tamilnadu and lies between at E10.37:76.97 latitude and 10.37 N 76.97 longitudes form a portion of Western Ghats Tamilnadu. It has an average elevation of the hills ranges between 1193 meters (3914 feet) and about temperature various between $23.6{ }^{\circ} \mathrm{C}$ to $19.9{ }^{\circ} \mathrm{C}$ and annual rainfall between $3523.3 \mathrm{~mm}$ to $2882.7 \mathrm{~mm}^{7}$.

Microbial natural products have been one of the major resources for discovery of novel drugs ${ }^{8}$. However, the study was focused with a single isolate, and the diversity of Nocardiopsis spp remained little explored. Thus, the aim of this study is to identify actinomycetes from the soil, investigate for their phenotypic, genotypic characteristics and bioactivity conditions against clinical pathogens associated with antibiotic resistance.

\section{MATERIALS AND METHODS}

\section{Soil Sampling and transport}

Soil samples were collected from different niche habitats of Valparai (latitude $10.37^{\circ} \mathrm{N}$ and longitude $76.97^{\circ} \mathrm{E}$. 3,914 feet) Taluk and hill station in the Coimbatore district of Tamil Nadu, India. Samples were collected by inserting a sterilized polyvinyl corer into the sediments. The corer was sterilized with alcohol before sampling at each location. Each collection was made from $4 \mathrm{~cm}$ depth of the surface of ground. These samples were placed in sterile poly bags, sealed tightly, and transported immediately to the laboratory. These soil samples were air-dried for $3-4 \mathrm{~h}$ at $45^{\circ} \mathrm{C}$, crushed, and sieved prior to use for further.

\section{Isolation of actinobacteria}

Starch agar medium (Starch 2g, Peptone 0.5g, $\mathrm{NaNO}_{3}$ $0.2 \mathrm{~g}_{2} \mathrm{KPO}_{4} \quad 0.5 \mathrm{~g}, \mathrm{MgSO}_{4} \quad 0.5 \mathrm{~g}$, D.W $100 \mathrm{ml}$ ) was prepared and sterilized at $121^{\circ} \mathrm{C}$ in $15 \mathrm{lbs}$ pressure for $15 \mathrm{~min}$. Then it was supplemented with streptomycin 30 $\mu \mathrm{g} / 1$ to prevent the bacterial growth ${ }^{9}$. The medium was poured into the sterile Petri plates. The collected soil samples were diluted up to $10-6$ and $0.1 \mathrm{ml}$ of the diluted samples was spread over the starch agar medium. The inoculated plates were incubated at $30^{\circ} \mathrm{C}$ for 7 days. Replicates plates were maintained for each dilution. After incubation, the dominative actinobacterial colonies were purified by streak plate technique, sub-cultured and stored at $4^{\circ} \mathrm{C}$ on SPA slants for further.

\section{Colony morphology}

Colony morphology of the purified actinobacterial isolates on SPA medium were recorded with respect to colour of aerial spore mass, size and nature of the colonies, colour on the reverse side and diffusible pigmentation.

\section{Phenotypic characterization of isolate}

The biochemical characterization of Indole, MR, VP, Citrate, H2S Urease, Oxidase test, gelatin hydrolysis, starch hydrolysis, urea hydrolysis, acid production from different sugars, motility test, triple sugar iron (TSI) agar test, with Actinobacteria RRMVCBNR 1was performed and further carried genotypic characterization.

\section{Genotypic identification of the isolate}

\section{Isolation of chromosomal DNA}

Dominative isolate of Actinobacteria was grown up to the late exponential phase in Starch Peptone broth incubation at $30^{\circ} \mathrm{C}$, after 7 days cells were harvested and washed with Tris EDTA buffer to DNA isolation. Step 1- total genemic DNA were isolated by resuspending the cells and add $6 \mathrm{ml}$ lysis buffer with the concentration (20mM Tris: EDTA, pH 8.0;10-15 $\mu \mathrm{g}$ lysozyme and 50 $\mu \mathrm{g} / \mathrm{ml}$ Rnase) and incubated for $30-80 \mathrm{~min}$ at $37^{\circ} \mathrm{C}$ respectively, after that add $500 \mu \mathrm{l}$ of $2 \mathrm{M} \mathrm{NaCl}$ solutions. Step 2 the entire suspension was agitated on a vortex mixer until the cell suspension became semitransparent. After that cells were lysed by the adding of $1.2 \mathrm{ml}$ of $10 \%$ SDS solution. The lysates were incubated for $15-30 \mathrm{~min}$ at $65^{\circ} \mathrm{C}$. Step 3-after addition of $2.4 \mathrm{ml}$ of $5 \mathrm{M}$ potassium acetate, the solution was mixed and left in ice box for $20 \mathrm{~min}$. the precipitate was removed by centrifugation for $30 \mathrm{~min}$ at $6,000 \mathrm{rpm}$ and the volume of the supernatant was adjusted to $8 \mathrm{ml}$. Step 4-the DNA was recovered by precipitation with 2 volume of isopropanol. Step 5- the precipitate was dissolved in 600 $\mu \mathrm{l} / \mathrm{g}$ of $10 \mathrm{mM}$ Tris/ $1 \mathrm{mM}$ EDTA ( $\mathrm{pH} 8.0)$ and the aqueous phase was transferred to a $1.5 \mathrm{ml}$ micofuge tube. Subsequently, $75 \mu 13 \mathrm{M}$ sodium acetate and 500 $\mu \mathrm{l}$ isopropanol were added and the solution was centrifuged for $30 \mathrm{sec}$ to $2 \mathrm{~min}$. Step 6- the precipitate was washed with $70 \%$ cold ethanol, dried and dissolved in $100 \mu \mathrm{TE}$ buffer. Collected DNA was used for PCR amplification.

\section{PCR amplification}

In a $0.5 \mathrm{ml}$ PCR tube upstream primer $10 \mu \mathrm{l}\left(5^{\text {ee }}\right.$ -

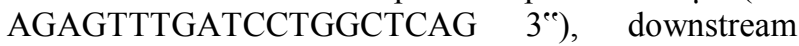
primer, $10 \mu \mathrm{l}$ (5"-AGGGCTACCTTGTTACGACTT 3"), 10× PCR buffer $10 \mu \mathrm{l}, 25 \mathrm{mM} \mathrm{MgCl} 28 \mu \mathrm{l}$, dNTP mix $6 \mu \mathrm{l}$, template DNA (50 ng), $5 \mu \mathrm{l}$ and Taq DNA polymerase $(3 \mathrm{U} / \mu \mathrm{l})$, sterile distilled deionized water 49 $\mu \mathrm{l}$ was taken in step 1 . The total $100 \mu \mathrm{l}$ mixture in a tube was gently spun for $10 \mathrm{sec}$. and allowed to settle the contents. The total mixture was kept in PCR thermal 
cycler in step 2. The amplification was carried out in 35 cycles, (denaturation for $60 \mathrm{sec}$. at $92^{\circ} \mathrm{C}$, primer annealing for $60 \mathrm{sec}$. at $54^{\circ} \mathrm{C}$ and polymerization for 90 sec. at $72^{\circ} \mathrm{C}$ ), after polymerization $10 \mu \mathrm{l}$ of PCR products with $2 \mu \mathrm{l}$ of loading dye was mixed and loaded on a $1.5 \%$ agarose gel and analysed electrophoretically at 60 volts for $45 \mathrm{~min}$ in step 3 . In step4- the gel was visualized on UV transilluminator and compared with $1 \mathrm{~kb}$ DNA ladder.

\section{Sequences accession number - NCBI-BLAST}

Then PCR product was sent to sequencing by automated sequenced method. The same primers as reported above were used for sequencing. Further, NCBI-BLAST www.ncbi.nlm.nih.gov/ blast was used to compare the sequence similarity of isolated actinobacteria strain with reference strain. The $16 \mathrm{~S}$ rRNA a sequence of actinobacteria was deposited in NCBI and the sequences accession number was obtained. The bootstrapped data set was used to build the phylogenetic tree by using the MEGA software.

16S rDNA secondary structure prediction of actinobacteria

The secondary structures of $16 \mathrm{~S}$ rDNA of actinobacteria (RRMVCBNR MG287120) were predicted using the bioinformatics tools available in online http://rna.tbi.univie.ac.at//cgi-bin/RNAWebSuite/ $\underline{\text { RNAfold.cgi?PAGE=3\&ID=19E2FPYxSh }}$

Restriction site analysis in 16S rDNA of actinobacteria

The restriction sites in $16 \mathrm{~S}$ rDNA of actinobacteria (RRMVCBNR MG287120) were analysed using NEB cutter programme version 2.0 tools in online http://nc2.neb.com/NEBcutter2/cutshow.php?name=91a a0161- and energy dot plot analysis by http://rna.tbi.univie.ac.at/RNAfold/19E2FPYxSh/sequen ce1_dp

\section{Extraction of actinobacterial extract}

Preparation of actinobacterial extract was done by submerged fermentation. Nocardiopsis flavescencs isolate was taken in $50 \mathrm{ml}$ of starch peptone broth in a 250-ml-capacity conical flask under sterile conditions and incubated at $30^{\circ} \mathrm{C}$ for 7 days at $150 \mathrm{rpm}$ rotation. After fermentation, the medium was centrifuged at $10,000 \mathrm{rpm}$ for $10 \mathrm{~min}$ to remove cells and debris and harvested for fermented broth and react with ethanol. Resultant fermented broth was used for further.

\section{Uropathogens}

The multi-drug resistant strains of uropathogens such as Bacillus subtilis, Staphylococcus aureus, Klebsiella pneumoniae, Salmonella typhi , E coli and Streptococcus pneumoniae,. were obtained from Microbiology unit, CBNR, Coimbatore, Tamilnadu.

\section{Primary screening of antibacterial against uro pathogen microorganism}

Antimicrobial activity was determined by conventional cross streak method. The isolated strains were streaked across the diameter on Muller Hinton Agar (MHA) plates. The plates were incubated at $28^{0} \mathrm{C}$ for $48 \mathrm{hrs}$. After observing the fine growth of the strain, the $24 \mathrm{~h}$ cultures of uropathogens were streaked perpendicular to the angle of central strip of the Nocardiopsis flavescencs culture. All plates were incubated at $37^{\circ} \mathrm{C}$ for $24 \mathrm{~h}$. After $24 \mathrm{~h}$, the antibacterial activities were observed based on the zone of inhibition.

\section{Scanning electron microscopy of intact colonies}

To morphological and architecture of colonies morphotypes, whole Nocardiopsis flavescencs colonies were removed from Starch peptone agar plates using a scalpel blade. Colonies were fixed for $18 \mathrm{~h}$ at $4^{\circ} \mathrm{C}$ in $3 \%$ glutaraldehyde in $0.1 \mathrm{M}$ phosphate buffer, $\mathrm{pH}$ 7.2. They were then immersed in liquid nitrogen for $30 \mathrm{sec}$ and freeze-dried for $90 \mathrm{~min}$ at $2 \times 10-3 \mathrm{MPa}$. Then, colonies were coated with gold (BALTEC SDC 050 Sputter Coater) and viewed in an ICON - Quanta 200 Mark II Scanning Electron Microscope at 30kV.

\section{RESULT}

Actinobacteria have been intensively studied in several under explored environments, niche, and extreme habitats in various parts of the world (including India) in the last few years. Yet, there is no report regarding isolation of actinobacteria from valparai, Coimbatore, Tamilnadu. In the present work among 8 actinobacteria strains were isolated from soil samples of niche habitats area (Figure 1) based on the colony morphology was differentiated. Colours of aerial spore mass of the isolates were categorized into 4 groups including white, grey, pink and brown series on Starch Peptone Agar. Among these 4 groups, most of the isolates were produced pink and white colour series than grey and brown series (Table. 1 Figure 2).
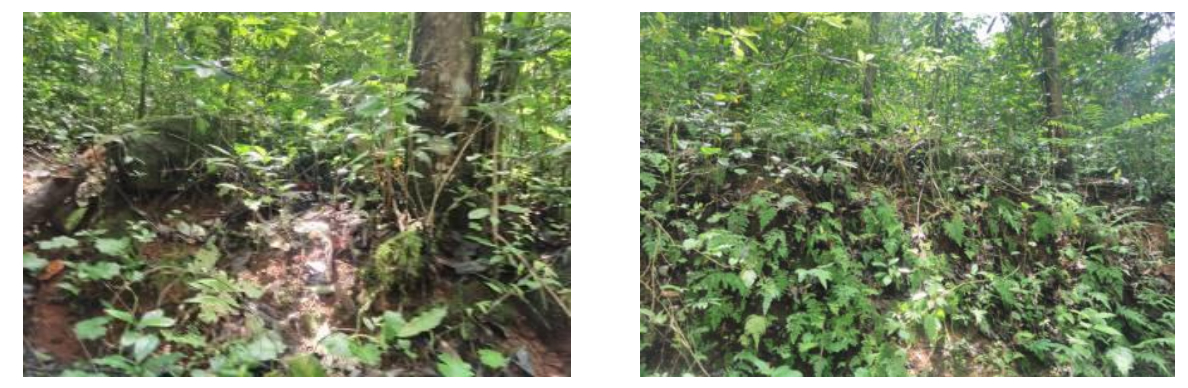

Figure 1: Panoramic view of sampling sites 1-4 
Table 1: Actinobacterial colonies were isolated from Soil samples from hills

\begin{tabular}{|c|c|c|c|}
\hline $\begin{array}{l}\text { Area of } \\
\text { collection }\end{array}$ & $\begin{array}{l}\text { Dilution } \\
\text { factor }\end{array}$ & Colony appearance & $\begin{array}{l}\text { Number of } \\
\text { colonies }\end{array}$ \\
\hline \multirow[t]{4}{*}{ Site 1} & \multirow{4}{*}{$10^{-5}$ to $10^{-9}$} & Small white +Very small + Milky white colony & $15+8+4$ \\
\hline & & Irregular white rough + Small creamy white & $2+3$ \\
\hline & & Small dot like + Whitish with zone like appearance & $7+6$ \\
\hline & & Pink coloured + Small white & $9+5$ \\
\hline \multirow[t]{4}{*}{ Site 2} & \multirow[t]{4}{*}{$10^{-5}$ to $10^{-9}$} & Big colonies with dot like appearance at centre & $8+10$ \\
\hline & & Small grey irregular + Irregular branched & $9+11$ \\
\hline & & Big grey & $2+2+2$ \\
\hline & & Big pink colonies + Radial spokes like colonies & $12+3$ \\
\hline \multirow[t]{3}{*}{ Site 3} & \multirow{3}{*}{$10^{-5}$ to $10^{-9}$} & Pink + Irregular colonies & $6+8$ \\
\hline & & brown with zone + Dot like colonies & $4+6$ \\
\hline & & Pink colonies & $17+5$ \\
\hline \multirow[t]{3}{*}{ Site 4} & \multirow[t]{3}{*}{$10^{-5}$ to $10^{-9}$} & pink with zone like appearance & $12+5$ \\
\hline & & Small dot like + Milky white colony & $4+7$ \\
\hline & & Small brown irregular + Pale white & $1+2$ \\
\hline
\end{tabular}
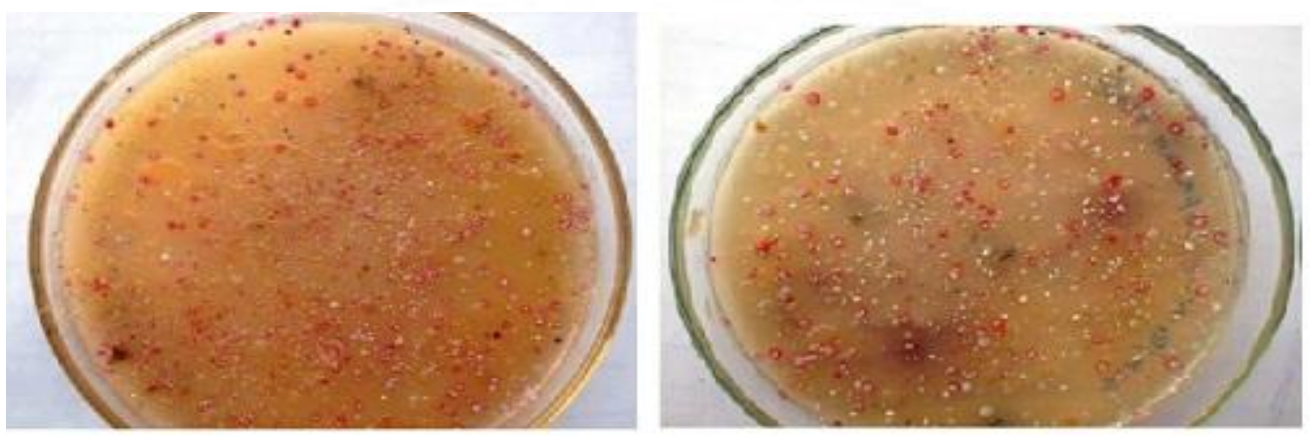

Figure 2: SPA medium with isolates

Further, many of the isolates produced pink coloured substrate mycelium (reverse side colour) on SPA medium after seven days of incubation at $28^{\circ} \mathrm{C}$. Based on the colony and microscopic (sporopore) morphology, most of the isolates $(66 \% ; \mathrm{n}=33)$ belonged to the genus Nocardiopsis and Nocardia, followed by Actinomadura
(12\%; n=6), Micromonospora $(4 \% ; \mathrm{n}=2)$ Actinoplanes and Actinopolyspora (each 2\%; $\mathrm{n}=1$ ) Therefore, an attempt has been made to isolate the actinomycetes from this unexplored region in order to find novel species (Table 2)

Table 2: Cultural and morphological characteristics of actinobacterial isolates

\begin{tabular}{|l|c|c|c|c|c|c|}
\hline Isolate Name & \multicolumn{2}{|c|}{ Colony morphology } & \multicolumn{4}{c|}{ Cell -Microscopic Observation } \\
\cline { 2 - 7 } & $\begin{array}{c}\text { Colour of aerial } \\
\text { spore mass }\end{array}$ & $\begin{array}{c}\text { Colour of } \\
\text { reverse side }\end{array}$ & Shape & $\begin{array}{c}\text { Aerial } \\
\text { Mycelium }\end{array}$ & $\begin{array}{c}\text { Substrate } \\
\text { Mycelium }\end{array}$ & $\begin{array}{c}\text { Colour of aerial } \\
\text { spore mass }\end{array}$ \\
\hline RRMVCBNR 1 & Pink & Pink & Spherical & Pink & Pink & Pink \\
\hline RRMVCBNR 2 & Grey & $\begin{array}{c}\text { Creamy } \\
\text { white }\end{array}$ & Spherical & Grey & Light grey & Grey \\
\hline RRMVCBNR 3 & Brown & Pale yellow & Ovoid & Brown & $\begin{array}{c}\text { Yellowish } \\
\text { brown }\end{array}$ & Brown \\
\hline RRMVCBNR 4 & White & White & Ovoid & White & Milky white & White \\
\hline RRMVCBNR 5 & Grey & Yellow & Ovoid & Grey & $\begin{array}{c}\text { White with } \\
\text { grey }\end{array}$ & Grey \\
\hline RRMVCBNR 6 & Brown & Yellow & Spherical & Brown & $\begin{array}{c}\text { Blackish } \\
\text { brown }\end{array}$ & Brown \\
\hline RRMVCBNR 7 & Grey & Dull white & Spherical & Grey & Light grey & Grey \\
\hline RRMVCBNR 8 & Brown & White & Spherical & Brown & Dull brown & Brown \\
\hline
\end{tabular}

Cultural characteristics of the isolate were studied with Starch Peptone Agar media. Eight of the isolates produced pink, white and grey coloured spore mass and white, brown and yellowish reverse side in most of the media tested. 


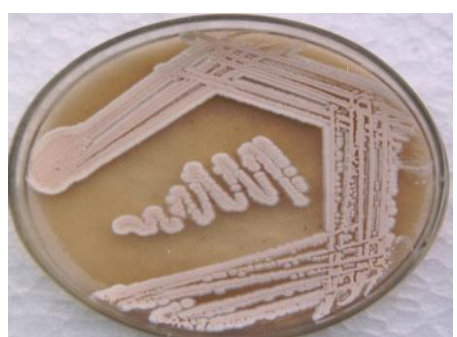

Figure 3: Actinobacterial isolate RRMVCBNR 1 steaked in SPA plate

Totally 8 actinobacterial strains were isolated based on the gram staining and colony morphology. All the isolates were found to be positive in gram staining and had different morphological structures. The biochemical properties of dominative actinobacterial isolate RRMVCBNR 1 were recorded. The dominative isolate was streaked on SPA plate and maintained (Figure 3)

Among the various biochemical characteristics studied, positive result were observed with potential isolate RRMVCBNR 1 in production of Indole, MR, citrate , urease, oxidase, starch hydrolysis ,Acid production from different sugars, motility, TSI and VP, gelatin hydrolysis and Urea hydrolysis negative results were observed (Table 3)

Table 3 Biochemical characteristics of the Actinobacterial isolate RRMVCBNR 1

\begin{tabular}{|l|l|l|l|l|l|l|}
\hline Isolate/Test & $\begin{array}{l}\text { Indole/ } \\
\text { MR/ }\end{array}$ & $\begin{array}{l}\text { Citrate/ } \\
\text { H2S }\end{array}$ & $\begin{array}{l}\text { Oxidase test/ } \\
\text { gelatin } \\
\text { hydrolysis }\end{array}$ & $\begin{array}{l}\text { starch } \\
\text { hydrolysis/ } \\
\text { urea hydrolysis }\end{array}$ & $\begin{array}{l}\text { Acid production } \\
\text { from different } \\
\text { sugars }\end{array}$ & $\begin{array}{l}\text { Motility test/ } \\
\text { triple sugar } \\
\text { iron }\end{array}$ \\
\hline RRMVCBNR 1 & $\begin{array}{l}\text { Ure } \\
+\mathrm{ve}\end{array}$ & $\begin{array}{l}+\mathrm{ve} \\
+\mathrm{ve}\end{array}$ & $\begin{array}{l}\text { +ve } \\
-\mathrm{ve}\end{array}$ & $\begin{array}{l}\text { +ve } \\
-\mathrm{ve}\end{array}$ & $\begin{array}{l}+\mathrm{ve} \\
+\mathrm{ve}\end{array}$ & $\begin{array}{l}+\mathrm{ve} \\
+\mathrm{ve}\end{array}$ \\
& & & & & \\
\hline
\end{tabular}

Based on the light and scanning electron microscopy, the antimicrobial producers formed straight to flexuous (rectiflexibiles) spore chain on aerial mycelium with smooth surface, The microscopical studies of the isolates undoubtedly placed these isolates under Nocardiopsis genera ( Figure 4)

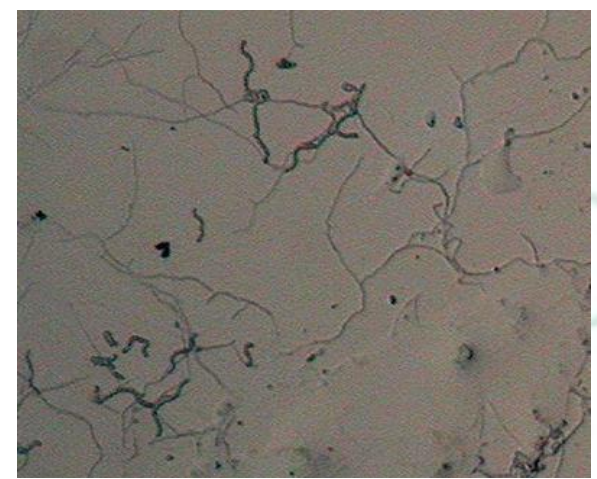

Figure: 4: Morphological features of Nocardiopsis flavescencs MG287120. Light microscopic images of spores,

(b) scanning electron microscope (SEM) images of mycelia 50 $\mu \mathrm{m}$.

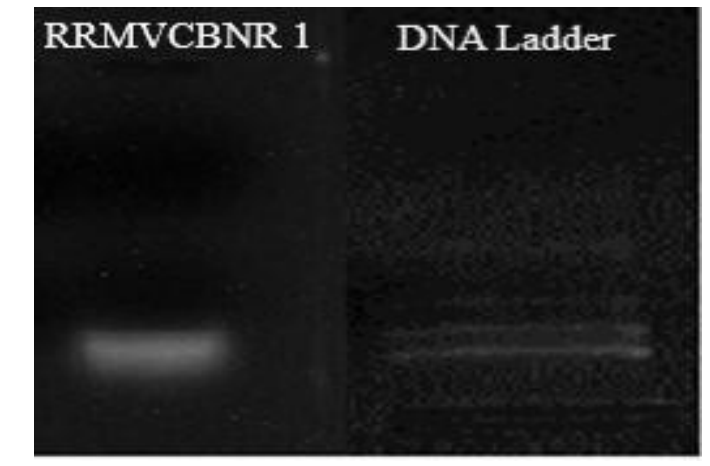

Figure 5: Bands obtained in agarose gel Lane 1RRMVCBNR 1, Lane 2- $1 \mathrm{~kb}$ Ladder
The isolated actinobacteria, genomic DNA was isolated with the DNA extraction method, amplified using the polymerase chain reaction and purified. Using the primers, the Size of fragments was obtained by amplification of 16s r-RNA region RRMVCBNR 1 100bp. (Figure 5,6)

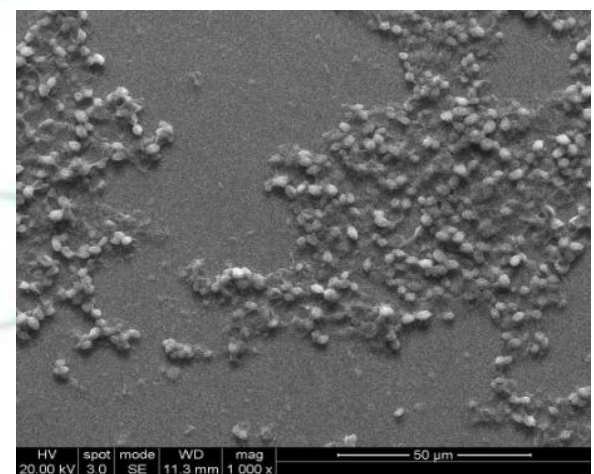

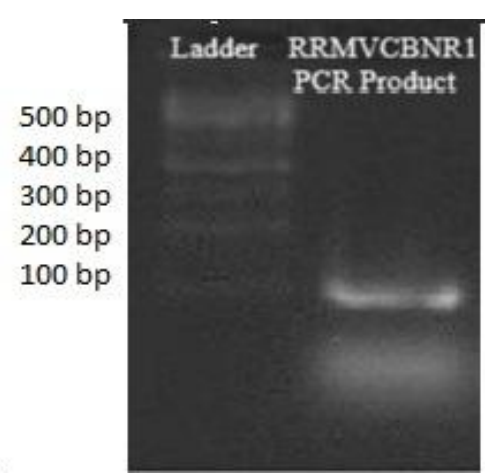

Figure 6: Bands obtained after amplification Lane 1RRMVCBNR 1, Lane 2 - 1 kb Ladder 
The isolated DNA was respectively amplified and sequenced (16S rRNA gene sequencing). The aligned sequences were regions of local similarity with known sequences in the Genbank database using nucleotide BLAST at the National Center for Biotechnology
Information (https://blast.ncbi.nlm.nih.gov/Blast). The isolated species were identifying based on homology scores with known species. Phylogenetic trees were constructed with robust phylogenetic tree software (Figure 6).

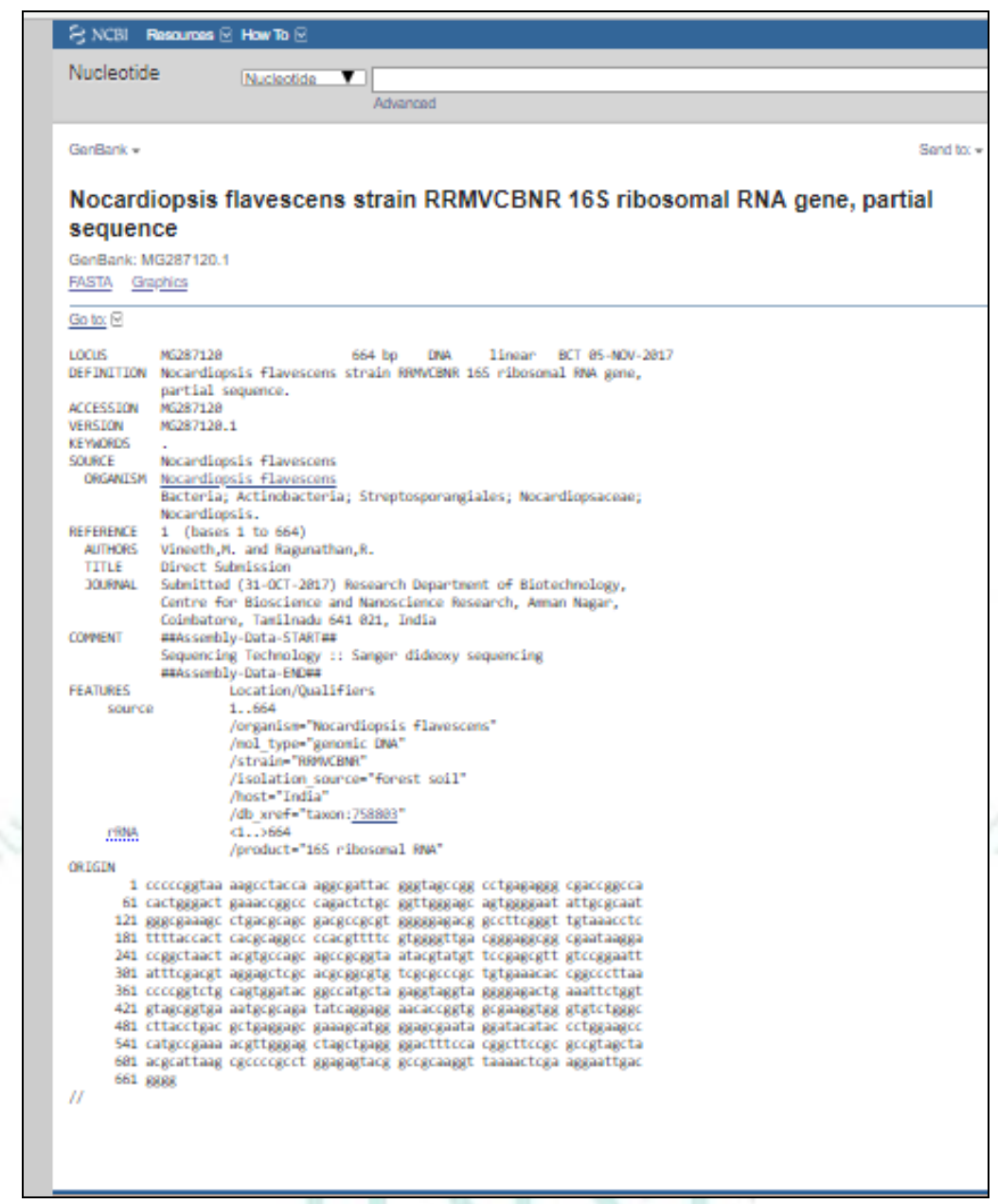

Figure 7: 16s r RNA partial sequence submission on NCBI

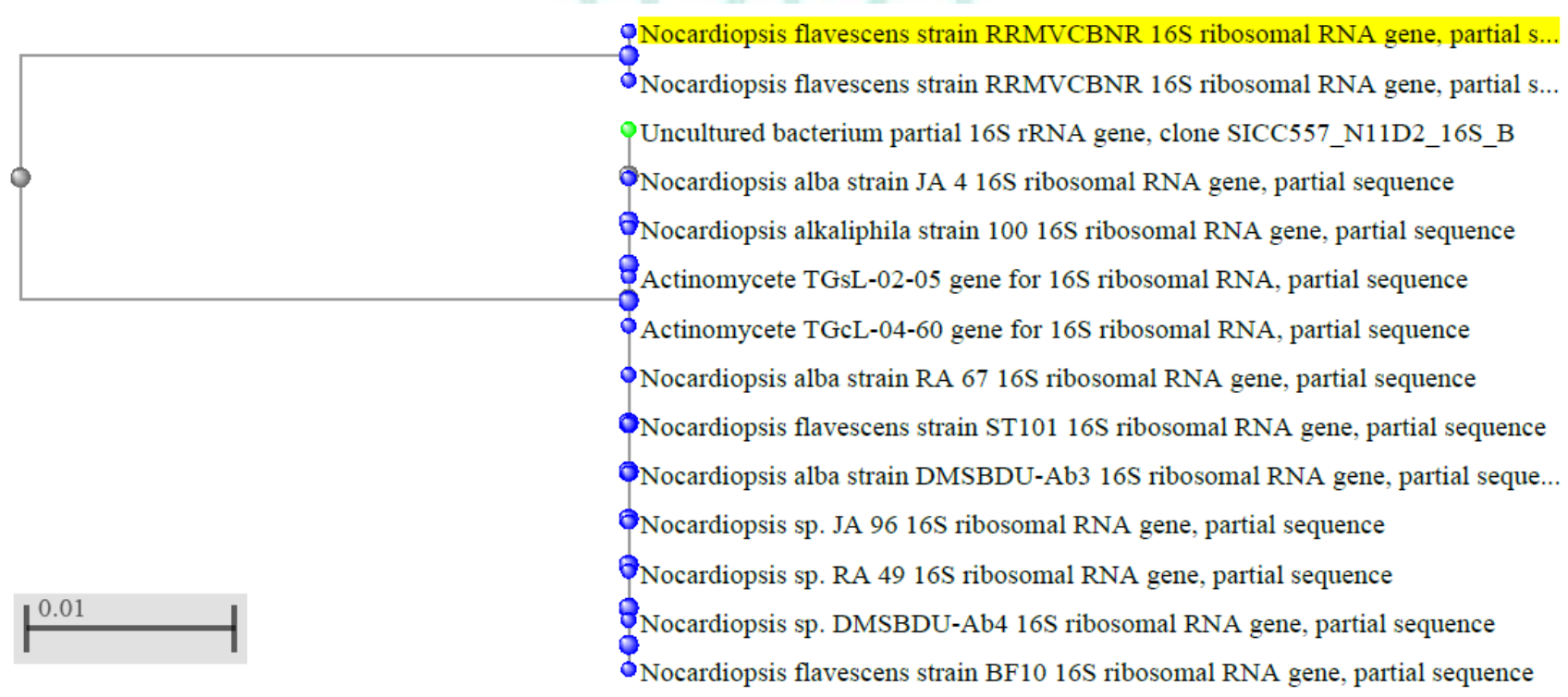

Figure 8: Phylogenetic tree showing phylogenetic position of the isolates 
In the phylogenetic tree, RRMVCBNR 1 was clustered together as one clade segments corresponding to an evolutionary distance of 0.01 are shown with bars. Numbers above branches are bootstrap values showing greater than $90 \%$ (Figure 7)

The secondary structure of 16S rRNA gene of Nocardiopsis flavescencs (MG287120) showed 45 stems in their structure. However, the isolate was similar in energy thresh hold, cluster factor, conserved factor, compensated factor, conservatively, part of sequence, greedy parameters and treated sequence as indicated by RNA fold web server software (Figure 8).

The restriction sites found in both Nocardiopsis flavescencs (MG287120). Totally, 47 restriction enzyme sites were observed however, the cleavage sites and nature of restriction enzymes. The GC, AT contents of were found to be $60 \%$ and $40 \%$ respectively (Figure 10).
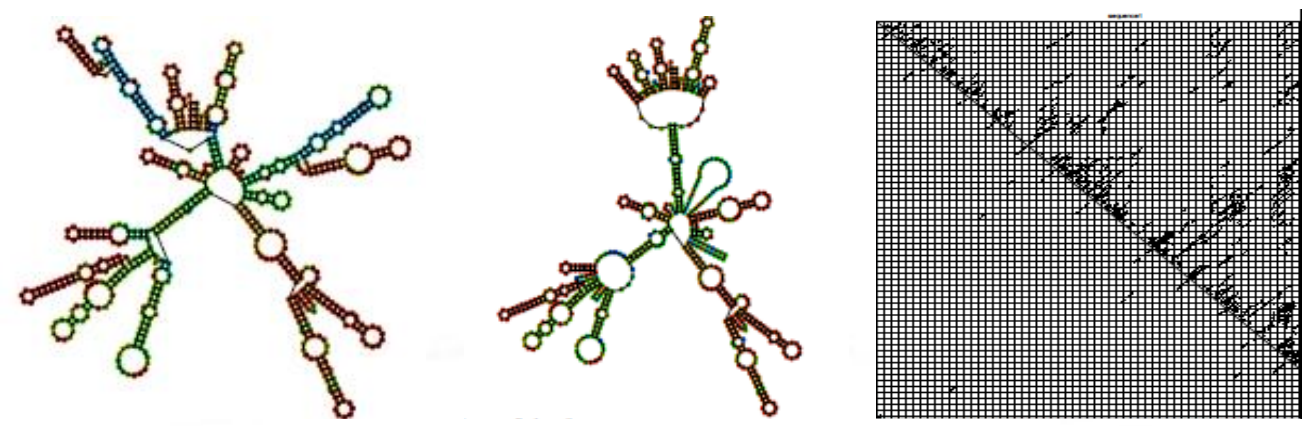

Figure 9: Secondary structures and Energy dot plot of 16S rDNA RRMVCBNR 1

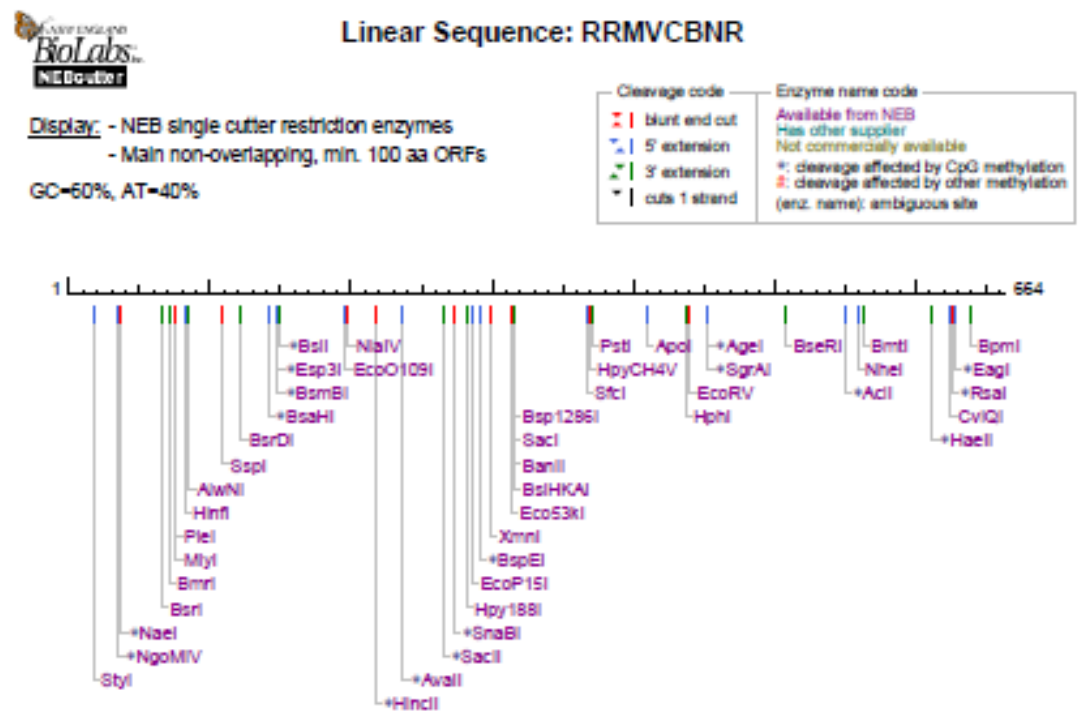

Figure 10: Restriction sites and GC content for RRMVCBNR 1

In the primary screening of antimicrobial activity against positive results Bacillus subtilis, Staphylococcus aureus, Klebsiella pneumoniae, Salmonella typhi , E coli and negative against Streptococcus pneumoniae,

The fermented broth containing antimicrobial compounds of selected potential Nocardiopsis flavescencs (MG287120) were extracted with ethanol solvents. The extracted compounds were assessed for their antimicrobial ability against positive results Bacillus subtilis, Staphylococcus aureus, Klebsiella pneumoniae, Salmonella typhi, E coli. The zones of inhibition were more sensitive in Staphylococcus aureus and Klebsiella pneumonia (Table 4).

Table 4: Antimicrobial efficacies of Nocardiopsis flavescencs (MG287120)

\begin{tabular}{|c|c|c|c|c|c|}
\hline Name of the isolate /Solvent & \multicolumn{5}{|c|}{ Diameter of inhibition zones (mm) } \\
\cline { 2 - 6 } & $\begin{array}{c}\text { Bacillus } \\
\text { subtilis }\end{array}$ & $\begin{array}{c}\text { Staphylococcus } \\
\text { aureus }\end{array}$ & $\begin{array}{c}\text { Klebsiella } \\
\text { pneumoniae }\end{array}$ & $\begin{array}{c}\text { Salmonella } \\
\text { typhi }\end{array}$ & $\begin{array}{c}\text { E coli } \\
\text { Nocardiopsis flavescencs } \\
\text { (MG287120 Ethanol }\end{array}$ \\
\hline
\end{tabular}




\section{DISCUSSION}

In previous study the isolation and characterization of microbial species are as important to understanding their existence in natural ecosystems. The isolation of diverse and novel actinobacteria provides a theoretical guide for the exploitation and utilization of actinobacterial resources. In this study isolation of actinobacteria from valparai, Coimbatore, Tamilnadu. Among 8 actinobacteria strains were isolated from soil samples of niche habitats area based on the colony morphology was differentiated. Among these 4 groups, most of the isolates were produced pink colour series than white, grey and brown series. Initially, actinobacteria were characterized on the basis of morphological characters so as to have a preliminary determination of the genus. In this study observed for several characters such as presence or absence of aerial and substrate mycelia, fragmentation or non fragmentation of substrate and aerial mycelium, presence of sclerotia, spore chain morphology and color of aerial spore mass in previously studied morphologically presence of mycelium. 11,12,13, Various biochemical characteristics of the actinomycetes are used for identification. ${ }^{14,15,16,17}$

It is also evident that $16 \mathrm{~S}$ rRNA gene sequencing has played a vital role in the identification of actinobacteria by many. ${ }^{18,19,20,21}$.

In this study isolate RRMVCBNR 1 in production of Indole, MR, citrate, urease, oxidase, starch hydrolysis, Acid production from different sugars, motility, TSI and VP, gelatin hydrolysis and Urea hydrolysis negative results. In previously Biochemical characterization of Streptomyces Spp. ${ }^{22,23,24,25}$ In the present study, distinct variation in the secondary structure, $\mathrm{G}+\mathrm{C}$ composition, presence of restriction enzymes sites in 16S rRNA gene sequence of isolates showed molecular level specificity of each and every individual isolates. For the development of universal identification system of not

\section{REFERENCES}

1. Meyer J, "Nocardiopsis, a new genus of the order Actinomycetales” Int. J. Syst Bacteriol, 1976; 26:487-493.

2. Srinivasan M C, Laxman RS, Deshpande M V, "Physiology and nutrition aspects of actinomycetes - an overview" World J. Microb. Biotechnol, 1991, 7:171-184.

3. Ravi Kumara, Smita Zinjardea, Vaishali Javdekarb, Tahsin Bennura, Ameeta, "Nocardiopsis species: Incidence, ecological roles and adaptations"Microbiological Research, 2015; 174:33-47

4. Anuprita A, Deshmukh, Narendra N, Vidhale, "Characterization of Novel Antibacterial Actinomycetes Strain N8 from Saline Soil of Vidarbha Region" Int. J. Life Sci. Biotech. Pharm. Res, 2015; 4(1):1-4

5. Chen YG, Cui XL, Kroppenstedt RM, Stackebrandt E, Wen $\mathrm{ML}, \mathrm{Xu} \mathrm{LH}$, "Nocardiopsis quinghaiensis sp. nov isolated from saline soil in China" Int. J. Syst. Evol. Microbiol, 2008; 58:699-705

6. Bouras N, Meklat A, Zitouni A, Mathieu F, Schumann P, Sproer C, "Nocardiopsis algeriensis sp. nov an alkalitolerant actinomycete isolated from Saharan soil".Antonie Van Leeuwenhoek, 2015; 107; 313-320.

7. Santhoshkumar S, Nagarajan N, AM fungal association in the Rhizosphere soil of some Pteridophytic plant species in only actinobacteria, but all microorganisms, a polyphasic taxonomic approach utilizing morphological, biochemical, physiological, cultural, ecological and molecular characteristics will help taxonomists for the development of meaningful taxonomic identification system. In previously taxonomic identification carried by many. $26,27,28,29$

In the course of screening for novel antimicrobial substances (antibiotics) from soil samples, Out of 8 actinobacteria found to have antimicrobial activity in preliminary screening, Nocardiopsis flavescencs (MG287120) was selected based on their zone of inhibition against Staphylococcus aureus and Klebsiella pneumonia.In previously antimicrobial activity were discussed by many others. ${ }^{30}$

\section{CONCLUSION}

It was concluded that Nocardiopsis flavescencs (MG287120) are omnipresent,they differed in their phenotypic and genotypic characterization depending on the physico-chemical properties and other nutrients of the habitats and also the isolate of Nocardiopsis varied in their antimicrobial activities; on the other hand most of the isolates showed morphological homology and phenotypic characteristics expressed much variations within the genus/species, therefore the genotypic characterization such as $16 \mathrm{~S}$ rRNA gene is a tool to find out its phylogeny, elucidating the secondary structure of rRNA and in the analysis of restriction sites and GC contents.

\section{ACKNOWLEDGEMENT}

The authors would like to thank Centre for Bioscience and Nanoscience Research, Coimbatore for valuable support. The authors are grateful to the Principal and Head, Department of Biotechnology Rathnavel Subramaniam College of Arts and Science, Coimbatore 641402 for technical assistance and support.
Valparai Hills, Western Ghats of Tamilnadu, India, Int. J. of Life Sciences, 2014; 3:201-206.

8. Meena B, Rajan LA, Vinithkumar NV, Kirubagaran R, "Novel marine actinobacteria from emerald Andaman and Nicobar Islands: a prospective source for industrial and pharmaceutical byproducts" BMC Microbiol, 2013; 13:145.

9. Meklat A, Sabaou N, Zitouni A, Mathieu F, Lebrihi A, "Isolation, taxonomy, and antagonistic properties of halophilic actinomycetes in Saharan soils of Algeria" Appl.Environ. Microbiol, 2011; 77:6710-6714.

10. Hotam S Chaudhary, Jayprakash Yadav, Anju R Shrivastava, Smriti Singh, Anil K Singh, Natrajan Gopalan, "Antibacterial activity of actinomycetes isolated from different soil samples of Sheopur (A city of central India)", 2013; 4(2):118-123

11. Tahsin Bennur, Ameeta Ravi Kumar, Smita Zinjarde, Vaishali Javdekar, "Nocardiopsis species: Incidence, ecological roles and adaptations" Microbiological Research, 2015; 174:33-47

12. Shade A, Hogan CS, Klimowicz AK, Linske M, McManus PS, Handelsman J, "Culturing captures members of the soil rare biosphere" Environmental Microbiology, 2012; 14:2247-2252. 
13. Gayathri A, Madhanraj P, Panneerselvam A, "Diversity, Antibacterial Activity And Molecular Characterization of Actinomycetes Isolated From Salt Pan Region of Kodiakarai,Nagapattinam DT" Asian J. Pharm. Tech, 2011; 1(3):79-81

14. Jeffrey LSH, Sahilah AM, Son R. Tosiah S, "Isolation and screening of actinomycetes from Malaysian soil for their enzymatic and antimicrobial activities" J. Trop. Agric. and Fd. Sc, 2007; 35(1):159-164

15. Ali Mohammed Abdullah Bawazir1, Ahmed Al-Haddad, Abdullah AL-Mahdi, Manjula Shantaram, "Actinomycetes from Mountains of Hadhramout - Yemen" Int.J.Curr.Microbiol.App.Sci, 2017; 8:3521-3530

16. Mukesh Sharma, Pinki Dangi, Meenakshi Choudhary, "Actinomycetes: Source, Identification, and Their Applications," Int.J.Curr.Microbiol.App.Sci, 2014; 3:801832

17. Joseph Devadass B, Gabriel Paulraj M, Ignacimuthu S, Agastian Simiyon Theoder P, Al Dhabi NA, "Identification of Antimicrobial Compounds from Streptomyces sp. Isolated from Western Ghats Soil in Tamil Nadu," EC Microbiology, 2017, 222-231.

18. Hozzein WN, Goodfellow M, "Nocardiopsis arabia sp. nov., a halotolerant actinomycete isolated from a sand-dune soil," Int. J. Syst. Evol. Microbiol, 2008; 58:2520-2524.

19. Tian S, Yang Y, Liu K, Xiong Z, Xu L, Zhao L, "Antimicrobial metabolites from a novel halophilic actinomycete Nocardiopsis terrae YIM 90022," Nat. Prod. Res, 2014; 28:344-346.

20. Jie Li, Jian Yang, Wen-Yong Zhu, Jie He, Xin-Peng Tian, Qiong Xie,Si Zhang, Wen-Jun Li, "Nocardiopsis coralliicola sp. nov., isolated from the gorgonian coral, Menella praelonga," International Journal of Systematic and Evolutionary Microbiology, 2012; 62:1653-1658

21. Sunita C,Mesta Onkarappa R, "Characterization and Antimicrobial Potential of Marine Actinomycetes From
Estuaries of Uttara Kannada District, Karnataka," Journal of Drug Delivery \& Therapeutics, 2017; 6:27-37

22. Virali MS, Vennila S, Vignesh S, Vikash K,Vijayakumar R, Panneerselvam A, "Antagonistic activity of actinomcyetes isolated from Marudhamalai Hills, Western Ghats," J. Soil Biol. Ecol, 2007, 27; 1(2):19-25.

23. Arifuzzaman M, KhatunM R, Rahman H, "Isolation and screening of actinomycetes from Sundarbans soil for antibacterial activity," Afr. J. Biotechnol, 2010; 9:46154619.

24. Basavaraj KN, Chandrashekhara S, Shamarez AM, Goudanavar PS, Manvi FV, "Isolation and morphological characterization of antibiotic producing actinomycetes," Trop. J. Pharm. Res, 2010; 9:231-236.

25. Deepa S, Panneerselvam A, Dhanasekaran D, Thajuddin N, Vijayakumar R, "Diversity and antimicrobial potential of actinobacteria from saltpan environment," Global Ad. Res. J. Microbiol, 2010; 1:140-148.

26. Kavitha A, Vijayalakshmi M, Sudhakar P, Narasimha G, "Screening of actinomycete strains for the production of antifungal metabolites," Afr. J.Microbiol. Res, 2011; 4:2732.

27. Monisha $\mathrm{K}$, Renu S, "Selective isolation of rare actinomycetes producing novel antimicrobial compounds," Int. J. Adv. Biotechnol. Res, 2011; 2:357-375.

28. Mythili B, Ayyappa Das MA, "Studies on antimicrobial activity of Streptomyces spp. isolates from tea plantation soil,’ Res. J. Agri. Sci, 2011; 2:104-106.

29. Nithya B, Ponmurugan P, "Studies on actinomycetes diversity in Eastern Ghats (Yercaud Hills) of Southern India for secondary metabolite production," Int. J. Agri. Res, 7:152-159.

30. Thakur D, Yadav A, Gogoi BK, Bora TC, "Isolation and screening of Streptomyces in soil of protected forest areas from the states of Assam and Tripura, India, for antimicrobial metabolites" J. Med. Mycol, 2007; 17:242-249. 